Keywords:

Surface roughness

Temperature

Surface Quality

Historic:

Recebido 02/05/20 I I

Aceito 24/07/2014

Palavras chave:

Rugosidade

Temperatura

Qualidade superficial

Correspondence: frezzatti@yahoo.com.br
Manoel Cléber de Sampaio Alves', Luiz Fernando Frezzatti Santiago', Marcos Tadeu Tiburcio Gonçalves ${ }^{2}$, Ivaldo De Domênico Valarelli³ ${ }^{3}$ Francisco Mateus Faria de Almeida Varasquim $^{4}$

\section{EFFECTS OF BELT SPEED, PRESSURE AND GRIT SIZE ON THE SANDING OF Pinus elliottii WOOD}

ABSTRACT: The present paper aims to evaluate the influence of the factors (belt speed, pressure and grit size) on the output parameters (temperature and surface roughness) for Pinus elliottii wood sanding, processed parallel to the fibers. Three levels of belt speed, three levels of pressure and four levels of grit size were employed, with six replicates for each process, totaling 216 observations. The experiment conducted under a randomized complete block design (RCBD). The results were analyzed employing the analysis of variance (ANOVA) with $5 \%$ of significance level. Only grit sizes were significant to different temperature levels. The same outcome was observed for roughness, where only grits sizes were significant. No interaction between the pressure and belt speed factors were observed for all the results analyzed.

\section{EFEITOS DA VELOCIDADE, PRESSÃO E GRANULOMETRIA DE LIXA NO LIXAMENTO DA MADEIRA DE Pinus elliottii}

RESUMO: Neste trabalho, objetivou-se observar o efeito dos fatores de entrada (velocidade, pressão e granulometrias de lixa) sobre as variáveis de saída (temperatura e rugosidade) no processo de lixamento plano do Pinus elliottii, processados paralelo às fibras. Foram utilizadas três velocidades, três pressões, quatro granulometrias de lixa com seis repetições para cada combinação, totalizando 216 tratamentos. $O$ experimento foi planejado para um delineamento em blocos completamente aleatorizados (DBC). Os resultados foram analisados por meio de uma análise de variância (ANOVA) com nível de significância de $5 \%$. Para a temperatura, observou-se que somente a granulometria de lixa teve uma influência significativa no aquecimento do sistema. Da mesma forma, a apenas a granulometria de lixa influenciou significativamente na rugosidade. Não foi observada interação entre os fatores pressão e velocidade para todos os resultados analisados.

\footnotetext{
' Universidade Estadual Paulista - Guaratinguetá, São Paulo, Brasi

2 Universidade Estadual Paulista - Itapeva, São Paulo, Brasil

${ }^{3}$ Universidade Estadual Paulista - Bauru, São Paulo, Brasil

${ }^{4}$ Instituto Federal de São Paulo - Itapetininga, São Paulo, Brasil
} 


\section{INTRODUCTION}

It is important to understand the influence of factors on the output parameters concerning sanding process, in order to contribute to the development of the wood sector, which, many times, employs empirical data, based on experience, without scientific proofs. Sanding process factors correspond to independent variables, and may be related to the equipment or the environment. However, the output parameters correspond to the variables depending on the combinations of the factor levels. Surface roughness can be an example of output parameter, which is employed in several machining processes. Understanding the influence of the combination of factors on the output parameters results in better processed material, hence increasing the quality of the final product.

According to Saloni (2007), sanding process involves the modification of the surface by the action of abrasive materials. Sanding process can be divided into two classes of work. The first class of work is to reduce the rough surface of a previously machined workpiece to a relatively smooth, flat surface; the second class of work, prepares the wood surface for a subsequent application of finishing material $(\mathrm{KOCH}, 1964)$.

According to Moura and Hernandez (2006), the correct choice between abrasive, sequence of grit size and feed speed, will influence the time for coating absorption, surface finishing and damages of sanded wood. Some papers by Carrano (1997), Saloni et al. (2005) and Taylor et al. (1999), aimed to understand the influences and interactions of several parameters related to sanding process. In fact, the field of abrasive machining must be broadly studied, due to the great variability presented by several factors which comprise this process and directly influence the final results.

According to Saloni (2007), several factors will influence output parameters, such as: pressure, belt speed, abrasive type, grit size, wood species, physical and chemical wood properties and wood anatomy. When all these factors are combined, sanding process becomes a difficult operation to be mathematically modeled. Pressure and belt speed exert great influence over material removal rate. This fact was observed on the works by Franz and Hinken (1954), Javorek et al. (2006), Porankiewicz et al. (2010), Saloni et al. (2005) and Taylor et al. (1999).

Varanda et al. (2010), studied the influence of belt speed and grit sizes on the surface quality of Eucalyptus grandis wood, and concluded that smaller abrasive grains produced better surface finishing.
Ratnasingam et al. (1999), observed that higher belt speeds could increase the temperature, harming both the abrasive and the machined material. Either for pressure as for belt speed, Taylor et al. (1999) did not observe any surface roughness improvements for the wood species tested. Concerning the type of abrasive, most of the studies report that silicon carbide provides better surface finishing, in relation to aluminum oxide. However, Moura and Hernandez (2006), reported that aluminum oxide provides a fluid absorbing surface in a shorter period, in relation to silicon carbide, for the wood species studied.

Wood may present great variability, due to its physical, chemical and anatomical properties, there may be alterations among each species. According to Ratnasingam et al. (1999), higher density wood causes more friction during sanding, and consequently higher temperatures on the interface between the sandpaper and the workpiece (wood). These authors explain that the effect of the temperature is aggravated when species have extractives (resin) which increase the loading over the abrasive. Liquefied resin flows onto the sandpaper, which after cooling decreases cutting capacity, increasing temperature. The present paper aims to study the influence of the input factors (belt speed, pressure and grit size) on the output parameters (temperature and surface roughness) for sanding Pinus elliottii wood, processed parallel to the fibers.

\section{MATERIAL AND METHODS}

The wood species employed was Pinus elliottii var. elliottii (40 year), from southeastern São Paulo State, Brazil. The final dimensions of the workpieces were: 50 $\mathrm{mm}$ (width), $30 \mathrm{~mm}$ (length) and $20 \mathrm{~mm}$ (thickness). These dimensions are the same used for determining wood moisture content (ASSOCIAÇÃO BRASILEIRA DE NORMAS TÉCNICAS - ABNT, 1997).

According to standard NBR 7I90 (ABNT, 1997), the workpieces were stored in a controlled environment chamber, in order to obtain the desired 12 percent moisture content. Sanding orientation was always parallel to the grain. The radial and tangential surfaces of the wood were selected at random.

A belt sander machine (Figure I), was used, with the followings dimensions: $530 \mathrm{~mm}$ (length), 160 $\mathrm{mm}$ (width) and $810 \mathrm{~mm}$ (height). A frequency inverter brand WEG ${ }^{\text {'m }} \mu$ line model was used to change the speed belt. The mechanism was developed in order to insert weights on the sander support, to apply pressure to the 
workpiece (Figurel). Sanding cycle time was selected based on preliminary research, providing that 20 seconds was enough time to remove sanding marks from the previous process. The abrasive used in this experiment was aluminum oxide, brand Norton abrasive. The sandpaper was stored according to the standard NBR I 4960 (ABNT, 2003).

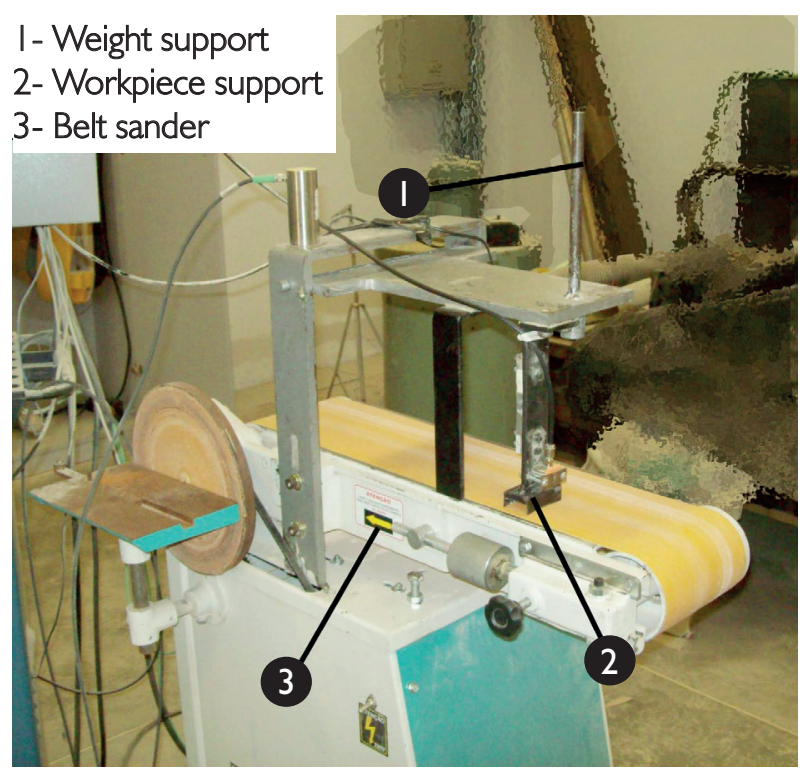

FIGURE 1 Belt sander used in the experiment.

FIGURA 1 Lixadeira plana utilizada no experimento.

A stylus type profilometer TAYLOR HOBSON brand model Surtronic $25+$ was used In to measure the surface roughness. Roughness average (Ra) constituted the parameter employed to represent the surface. The Robust Gaussian filter was selected with the cutoff length equal to $2.5 \mathrm{~mm}$ (GURAU et al., 2006). Measurements in six different randomly selected spots of the surface were averaged. An infrared camera FLIR i5 brand, 0.95 emission, was employed to measure the sanding temperature. The infrared camera was placed at $90^{\circ}$, in relation to the sanding machine, at a one meter distance. The highest temperatures were measured, for each combination.

A randomized complet block design (RCBD) was employed for the experiment. The levels of factors considered in the experiment were: four grit sizes $(80$, 100,120 and 220), abrasive aluminum oxide $\left(\mathrm{Al}_{2} \mathrm{O}_{3}\right)$, three levels of pressure $(26,30$ and $33 \mathrm{kPa})$ and three levels of belt speed $\left(9, \mathrm{II}\right.$ and $\left.13 \mathrm{~m} \cdot \mathrm{s}^{-1}\right)$. The grit sizes were considered as a block, in which, for each grit size, belt speed and pressure were randomized. The treatments realized on the experiment for belt speed, pressure and grit sizes $(3 \times 3 \times 4=36)$ were run with six replicates, totaling 216 observations.

The results of the output parameters were analyzed through the analysis of variance (ANOVA) with significance level $5 \%$. The software $R$ version 2.0 .I was employed in the statistical analysis.

\section{RESULTS AND DISCUSSION}

The results analyzed on the following topics correspond to the physical properties of Pinus elliottii wood and the output parameters of the sanding process.

\section{Physical analysis of Pinus elliotti}

Table I shows the apparent density average value $\left(d_{\text {apm, } 12 \%}\right)$, average basic density $\left(d_{b m}\right)$, coefficient of variation $(\mathrm{CV})$, number of samples $(\mathrm{N})$ and the confidence interval $(\mathrm{Cl} ; \alpha=0.05)$. According to Carvalho and Rocco Lahr (2007), the apparent density value ( $12 \%$ moisture content) for Pinus elliottii, range from $450-600 \mathrm{~kg} \cdot \mathrm{m}^{-3}$. The results obtained in the present study for Pinus elliottii are in accordance to this range. According to Santini et al. (2000), the basic density of Pinus elliottii, range from $470-540 \mathrm{~kg} \cdot \mathrm{m}^{-3}$, and this value varies according to wood age, place in which the trees were raised, position on the tree and other factors. The basic density value found in the present study is also within the range for Pinus elliottii species.

TABLE I Basic and apparent average densities for Pinus elliottii.

TABELA I Densidade média básica e aparente para o Pinus elliottii.

\begin{tabular}{lcccc}
\hline & $\mathrm{d}\left(\mathrm{kg} \cdot \mathrm{m}^{-3}\right)$ & $\mathrm{CV}(\%)$ & $\mathrm{N}$ & $\mathrm{Cl}$ \\
\hline $\mathrm{d}_{\text {apm, } 12 \%}$ & 554.47 & $\mathrm{II} .92$ & 20 & $(523.54 ; 585.40)$ \\
$\mathrm{d}_{\mathrm{bm}}$ & 449.17 & 14.31 & 30 & $(425.17 ; 473.17)$ \\
\hline
\end{tabular}

\section{Temperature during sanding process}

The effect of temperature upon sanding, was significant only for the grit sizes $\left(F_{3,204}=9.5473\right.$; $p$-value $<0.05$ ). A tendency for temperature elevation was observed, according to grit size increase (Figure 2). This phenomenon occurs due to the greater amount of grains in contact with the wood, in which these grains are smaller and remove smaller amounts of material, thus, increasing the friction between the sandpaper and wood sanded. 
The effect of belt speed was not significant for sanding temperature $\left(\mathrm{F}_{2,204}=2.9350 ; \mathrm{p}\right.$-value $\left.>0.05\right)$, as well as pressure was not significant for temperature $\left(F_{2,204}=2.07382 ; \mathrm{p}\right.$-value $\left.>0.05\right)$. Figure 3 shows belt speed and pressure in relation to temperature, and there is not a tendency of temperature variation for the levels of these factors. A possible explanation is that this species presents medium density, which makes material removal relatively easy, not causing so much friction over the sanding area, consequently not presenting severe variation of temperature when belt speed and pressure were altered.

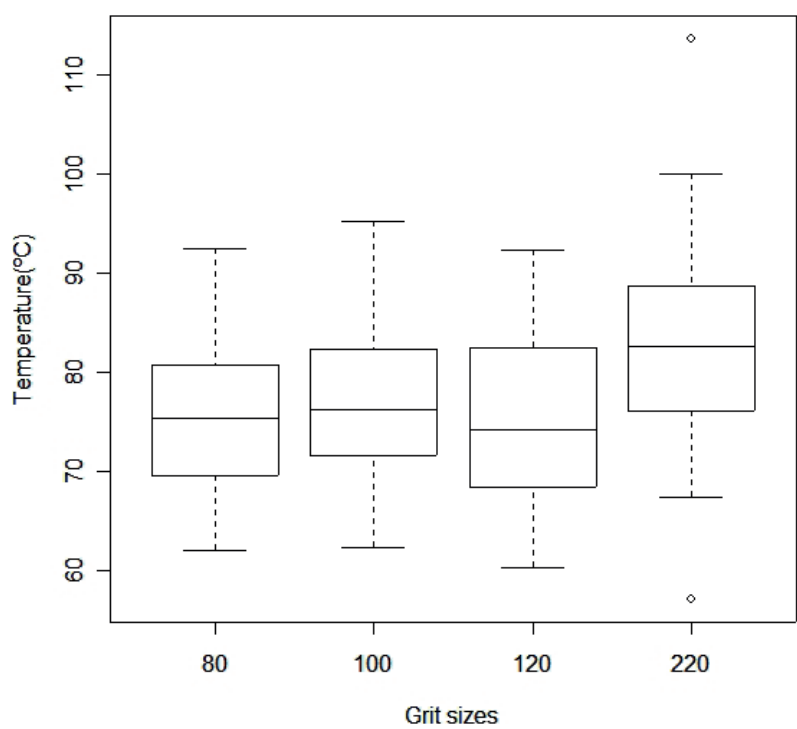

FIGURE 2 Influence of the grit sizes over temperature. FIGURA 2 Influência da granulometria sobre a temperatura.
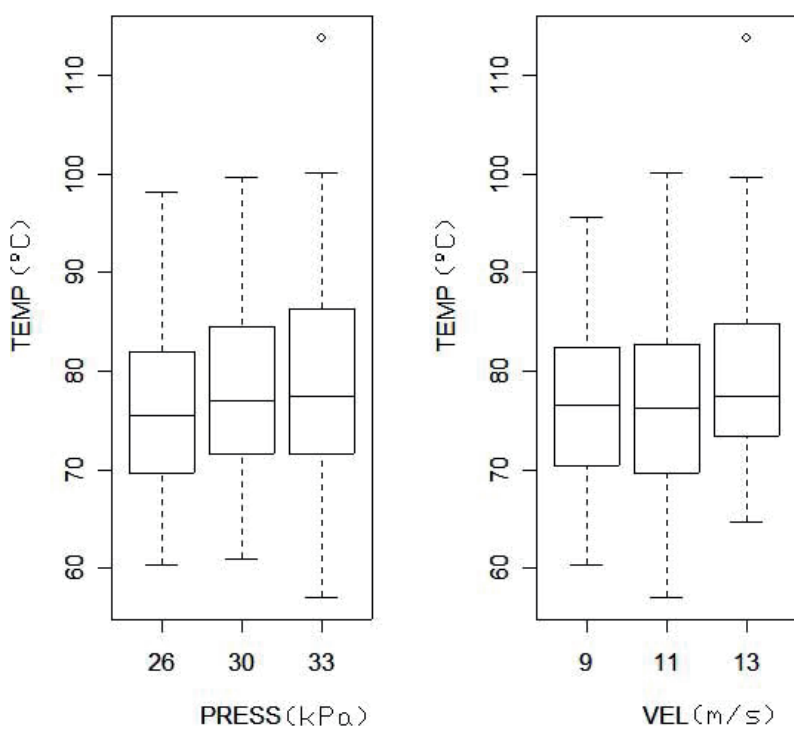

FIGURE 3 Influence of pressure and belt speed over temperature. FIGURA 3 Influência da pressão e velocidade na temperatura.
There was no interaction between the factors, belt speed and pressure $\left(F_{4,204}=0.3183 ; p\right.$-value $\left.>0.05\right)$. Figure 4 shows belt speed and pressure over temperature and it was not observed any interaction between the factors.
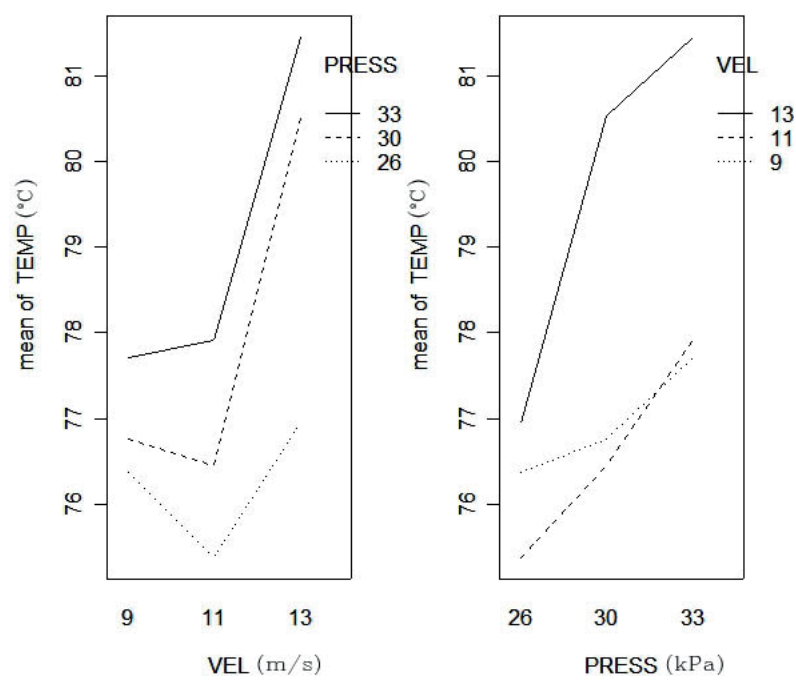

FIGURE 4 Interaction between the factors concerning temperature. FIGURA 4 Interação entre os fatores para temperatura.

\section{Surface roughness}

The effect of surface roughness on the sanding process was significant only for the grit sizes $\left(\mathrm{F}_{3,204}=\right.$ 371.2195; p-value <0.05). Figure 5 shows significant variation of the grit size influence over surface roughness.

This trend observed (Figure 5) on the grit sizes was expected for surface roughness. It was observed that the coarse grit produces rougher surface than the smooth grit. Differently from the grit size, the belt speed and pressure, which were not significant in the variance analysis, according to the statistic results for belt speed $\left(F_{2,204}=1.376 \mathrm{I} ; \mathrm{p}\right.$-value $\left.>0.05\right)$ and pressure $\left(\mathrm{F}_{2,204}=\right.$ $0.4699 ; p$-value $>0.05)$. Similar results were found by Varasquim et al. (2012) on the sanding of Eucalyptus grandis wood.

Figure 6 shows that there is no influence of belt speed and pressure on the surface roughness for Pinus elliottii wood.

Taylor et al. (1999), studied some input factors on output parameters for sanding process, and these authors have not found any significant influence of the pressure over surface roughness, concerning three hardwood species (Acer saccharum, Quercus alba, Prunus serotina) and one softwood species (Pinus 
strobus). Saloni et al. (2005), obtained similar results in their work. But differently from Taylor et al. (1999), these authors have also studied the influence of belt speed on surface roughness. These authors have not found statistically significant difference on surface roughness when the belt speed was altered for the species studied.

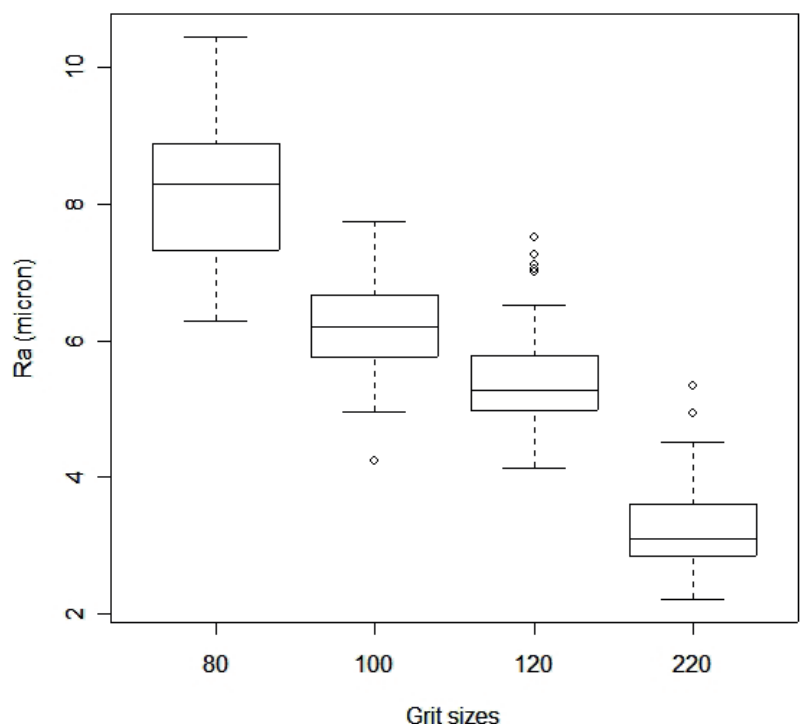

FIGURE 5 Influence of the grit sizes over surface roughness. FIGURA 5 Influência da granulometria sobre a rugosidade.
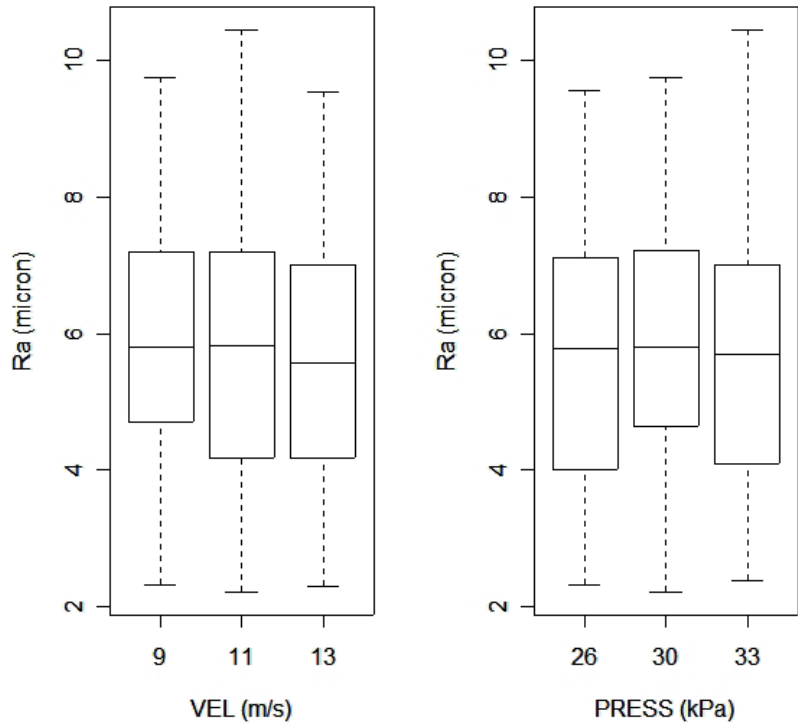

FIGURE 6 Influence of belt speed and pressure over surface roughness.

FIGURA 6 Influência da pressão e velocidade na rugosidade.

There was not any interaction between belt speed and pressure, over surface roughness $\left(\mathrm{F}_{4,204}=\right.$ 0.2956; $p$-value $>0.05$ ). Figure 7 shows belt speed and pressure over surface roughness and no interaction was observed between these factors.
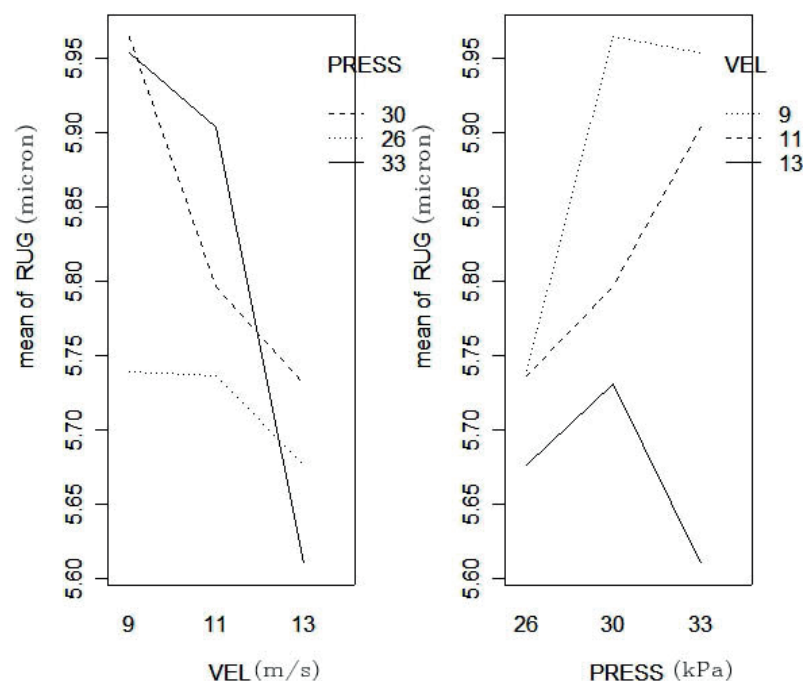

FIGURE 7 Interaction between the factors over surface roughness.

FIGURA 7 Interação entre os fatores para rugosidade.

\section{CONCLUSIONS}

Due to the combination of the factors (pressure, belt speed and grit size) the following conclusions concerning the variations of the output parameters (temperature and roughness) of sanding process can be made:

No interaction was found between the factors, pressure and belt speed, in relation to all the output parameters measured during the experiment;

Surface roughness was influenced significantly only by the grit size, in which the coarse grit produced a rougher surface than the smooth grit. The levels of the input factors used in this experiment (belt speed and pressure) did not influence the surface roughness of Pinus elliottii wood sanding process;

The temperature was significantly influenced only by the grit sizes, in which the smooth grit produces a higher temperature than coarse grit. The input factors levels of belt speed and pressure did not depend on the temperature of Pinus elliottii wood sanding process.

\section{ACKNOWLEDGMENTS}

Our special thanks go to all the institutions which contributed to make this research possible, particularly to FAPESP - Fundação de Amparo à Pesquisa 
do Estado de São Paulo (Brazil), for a research grant, and UNESP - Universidade Estadual Paulista at Itapeva-SP, for making its Wood Machining Laboratory available for the development of this work.

\section{REFERENCES}

ASSOCIAÇÃO BRASILEIRA DE NORMAS TÉCNICAS. NBR 7190: projeto de estruturas de madeira. Rio de Janeiro, 1997.

\section{ASSOCIAÇÃO BRASILEIRA DE NORMAS TÉCNICAS. NBR} 14960: abrasivos revestidos: lixas: requisitos de segurança para seu uso. Rio de Janeiro, 2003.

CARRANO, A. Quantification of effect of process parameters and their interactions with respect to material removal rate and surface roughness for a wood sanding process in the furniture making industry. 1997. 196 p. Thesis (Master in Industrial Engineering Department) - Faculty of North Carolina State University, Raleigh, 1997.

CARVALHO, J. S.; ROCCO LAHR, F. A. Contribuição para a definição de critérios para o dimensionamento da ligação entre peças estruturais de madeira por chapas metálicas com dentes estampados. Cadernos de Engenharia de Estruturas, São Carlos, v. 9, n. 36, p. 49-63, 2007.

FRANZ, N. C.; HINKEN, E. W. Machining wood with coated abrasives. Journal Forest Products Research Society, Michigan, v. 4, n. 5, p. 25I-254, 1954.

GURAU, L.; MANSFIELD-WILLIANS, H.; IRLE, M. Filtering the roughness of a sanded wood surface. Holz als Roh und Werkstoff, Berlin, v. 64, n. 5, p. 363-37I, Jan. 2006.

JAVOREK, L.; HRIC, J.; VACEK, V. The study of chosen parameters during sanding of spruce and beech wood. ProLigno, Brasov, v. 2, n. 4, p. I-II, Dec. 2006.

$\mathrm{KOCH}, \mathrm{P}$. Wood machining process. New York: Ronald, 1964. $530 \mathrm{p}$
MOURA, F. L.; HERNANDEZ, E. R. Effects of abrasive mineral, grit size and feed speed on the quality of sanded surfaces of sugar maple wood. Wood Science and Technology, Berlin, v. 40, n. 6, p. 5I7-530, Mar. 2006.

PORANKIEWICZ, B.; BANSKI, A.; WIELOCH, G. Specific resistance and specific intensity of belt sanding of wood. BioResources, Oxford, v. 5, n. 3, p. 1626-1660, 2010.

RATNASINGAM, J.; REID, H. F; PERKINS, M. C. The productivity imperatives in coated abrasives: application in furniture manufacturing. Holz als Roh und Werkstoff, Berlin, v. 57, n. 2, p. II7-I20, Apr. 1999.

SALONI, D. E. Process monitoring and control system design, evaluation and implementation of abrasive machining processes. 2007. 197 p. Thesis (Ph.D. in Industrial Engineering) - Faculty of North Carolina State University, Raleigh, 2007.

SALONI, D. E.; LEMASTER, R. L.; JACKSON, S. D. Abrasive machining process characterization on material removal rate, final surface texture, and power consumption for wood. Forest Products Journal, Madison, v. 55, n. I2, p. 35-52, Dec. 2005.

SANTINI, E. J.; HASELEIN, C. R.; GATTO, D. A. Análise comparativa das propriedades físicas e mecânicas da madeira de três coníferas de florestas plantadas. Ciência Florestal, Santa Maria, v. I0, n. I, p. 85-93, 2000.

TAYLOR, J. B.; CARRANO, A. L.; LEMASTER, R. L. Quantification of process parameters in a wood sanding operation. Forest Products Journal, Madison, v. 49, n. 5 , p. 4I-46, 1999.

VARANDA, L. D.; ALVES, M. C. S.; GONÇALVES, M. T. T.; SANTIAGO, L. F. F. Influência das variáveis no lixamento tubular na qualidade das peças de Eucalyptus grandis. Cerne, Lavras, v. I6, p. 23-32, 20I0. Suplemento.

VARASQUIM, F. M. F. A.; ALVES, M. C. S.; GONÇALVES, M. T. T.; SANTIAGO, L. F. F.; SOUZA, A. J. D. Influence of belt speed, grit sizes and pressure on the sanding of eucalyptus grandis Wood. Cerne, Lavras, v. I8, p. 23I-237, 2012. 